Bangladesh J. Bot. 44(1): 31-36, 2015 (March)

\title{
POLLEN MICROMORPHOLOGY OF FOUR TAXA OF ANEMONE CORONARIA L. FROM WESTERN TURKEY
}

\author{
Feyza Candan* and İlkay Öztürk Çali ${ }^{1}$ \\ Department of Biology, Arts and Science Faculty, Celal Bayar University, Manisa, Turkey
}

Key words: Pollen micromorphology, Anemone coronaria L., Four taxa

\begin{abstract}
The present study examined a comparison of the pollen micromorphology of four taxa of Anemone coronaria L. (A. coronaria var. coccinea (Jord.)) Burn, A. coronaria var. rosea (Hanry) Batt, A. coronaria var. cyanea, A. coronaria var. alba Goaty \& Pens) naturally distributed in western Turkey and its commercial cultivars of de Cean group. Measurements of pore width-length and exine-intine layer thicknesses were made using a micrometric ocular. In this study pore width-length and exine-intine layer thicknesses were found as decreased in all Anemone coronaria L. cultivars of de Cean group in respect to the varieties. The reasons for this variation could be the use of pesticides and tetraploid $\mathrm{F}_{1}$ hybrids of Anemone coronaria $\mathrm{L}$. cultivars of de Caen group by the producers.
\end{abstract}

\section{Introduction}

The genus Anemone L. sensu stricto belongs to Ranunculaceae and is distributed throughout the world. According to Ziman et al. (2008), this genus includes 15 subgenera, 23 sections, 4 subsections, 23 series and 118 species. Because of the taxon's worldwide distribution and considerable diversity in Anemone L. morphology, this genus has been studied for its chromosomes and genome (Heimburger 1962).

The species Anemone coronaria L. is known as the 'Tulip of Manisa' in Turkey. According to Davis (1965), there are four varieties of Anemone coronaria L. based on tepal colours in Turkey. These are A. coronaria var. coccinea (Jord.) Burn (with scarlet flowers), A. coronaria var. rosea (Hanry) Batt (with pink flowers), A. coronaria var. cyanea (with violet-blue flowers) and $A$. coronaria var. alba Goaty \& Pens (with white flowers). The A. coronaria L. is a multifunctional species, though recent cultivars have been largely selected for cut-flower production. A. coronaria L. cultivars are classified into two major groups: 'De Caen' and 'St. Brigid'. The cultivars included in this study belong to the 'de Caen' group, which is characterized by long stems and a single flower (Laura and Allavena 2007).

The aim of this study was to investigate the pollen micromorphology of four varieties and four commercial cultivars of Anemone coronaria species.

\section{Materials and Methods}

Plant specimens of the four varieties of Anemone coronaria L. were collected from areas near the Kırkağaç-Soma highway of Manisa, a city located in Western Turkey, in March 2011. The cultivars of the same species were obtained from the commercial flower growers in the Urla area of the city of İzmir.

In this study, the Anemone coronaria L. cultivar group of de Caen selections (scarlet, pink, violet-blue and white cultivars) was used. Tetraploid $\mathrm{F}_{1}$ hybrids were used as commercial forms in this study. Flora of Turkey (Davis 1965) was consulted for the taxonomic identification of the plant samples.

*Author for correspondence: <ilkaycali@hotmail.com>. ${ }^{1}$ Department of Biology, Arts and Science Faculty, Amasya University, Amasya, Turkey. 
Flower specimens from each group were fixed in the Carnoy's solution. The flowers were removed from the solution and then the anthers, taken from ripe floral buds with the help of a dissection needle, were mounted on a glycerine-gelatin-liquid safranine mixture (Wodehouse 1965). However, some preparations for the measurements were made according to Erdtman (1966) method. A total of 1000 pollens from each groups were used for the measurements of pore widthlength and exine-intine layer thicknesses in equatorial view. These were made with the help of a Leica ICC50 HD binocular light microscope by using a Leica Digital Camera. Some pollens of the varieties, the pure group, and the cultivars were photographed using a JEOL JSM-6060 Scanning Electron Microscope (SEM) (Nepi et al. 1995).

Statistical analyses of the values related to all measurements in the present study were made on a SPSS 20.0 for Windows statistical program. A multiple Range Tukey Test was used for variance analyses (Tukey 1954).

\section{Results and Discussion}

In this study, the pollen type of the varieties was found to be periporate and pollen shape prolate spheroidal (Fig. 1).

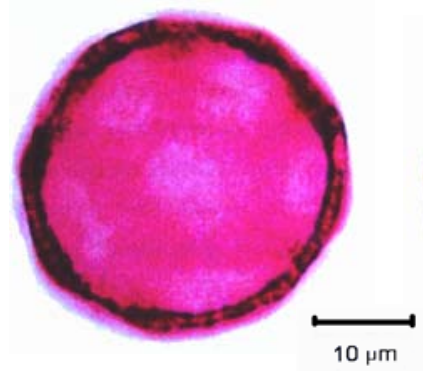

a

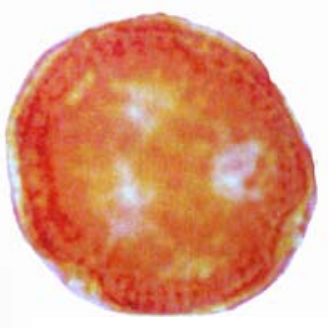

b

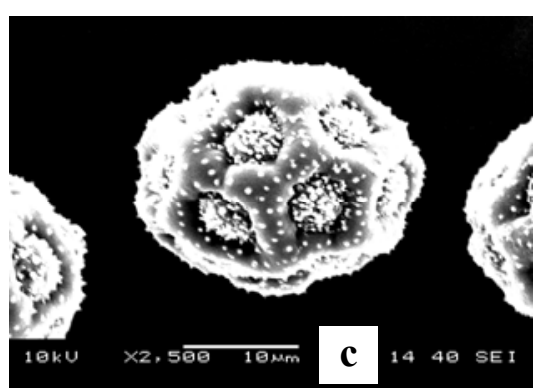

Fig. 1. The general appearance of the pollen in the pure Anemone coronaria var. coccinea (Jord.) Burn.

(a) Wodehouse Method is used. (b) Erdtman method is used. (c) Scanning electron microscope is used.

In addition, pollen structure was determined as tectate and sculpture as scabrate. Pores with unclear annulus, clear operculum and spinules were seen (Fig. 2a). A. coronaria var coccinea and A. coronaria var. cyanea pollens were found with 14 pores and A. coronaria var. purpurea and A. coronaria var. alba pollens with 16 pores.

The results of the exine and intine measurements of the pollen grains are shown in Table 1. As compared to the pure groups, the measurements of the exine and intine layers were generally lower in the commercial cultivars. Such a decrease in the exine measurements of the de Caen cultivar groups pollens except for Anemone coronaria pink cultivars group was statistically significant as compared to the pure groups $(\mathrm{p}<0.05)$. Meanwhile, the decrease that occured in the intine measurements of the de Caen cultivar group pollens as compared to the pure group except for Anemone coronaria pink cultivars and violet-blue cultivars groups was found to have a statistical significance $(\mathrm{p}<0.05)$.

According to Kamenetsky and Okubo (2013), the species of the genus Anemone L. are cultivated in greenhouses for the domestic consumption of cut flowers. It is known that some diseases are easily caused by the greenhouse conditions. Several fungicides are used to prevent the fungi Pythium, Botrytis and powdery mildew causing diseases in Anemone. In addition, several 
aphid species and red spider species are considered to be the major pests of Anemone. Some insecticides were also used against these pathogens. According to the breeding of Anemone coronaria L. cultivars, to bring forward the flowering, tubers can be vernalised before planting (Ohkawa 1987). Laura and Allavena (2007) reported that one of the processes after vernalising is disinfection with fungicides.

Table 1. Exine and intine measurements $(\mu \mathrm{m})$ of the pollen grains.

\begin{tabular}{lcc}
\hline Groups & \multicolumn{2}{c}{ Equatorial view } \\
\cline { 2 - 3 } & Exine $(\mu \mathrm{m})$ & Intine $(\mu \mathrm{m})$ \\
\hline A. coronaria var. coccinea (Pure) & $2.470 \pm 0.115^{\mathrm{b}}$ & $1.728 \pm 0.087^{\mathrm{b}}$ \\
A. coronaria scarlet cultivars of de Caen group & $1.605 \pm 0.109^{\mathrm{a}}$ & $1.301 \pm 0.057^{\mathrm{a}}$ \\
A. coronaria var. rosea (Pure) & $2.233 \pm 0.074$ & $1.461 \pm 0.075$ \\
A. coronaria pink cultivars of de Caen group & $1.958 \pm 0.117$ & $1.228 \pm 0.077$ \\
A. coronaria var. cyanea (Pure) & $1.953 \pm 0.085^{\mathrm{f}}$ & $1.693 \pm 0.066$ \\
A. coronaria violet-blue cultivars of de Caen group & $1.361 \pm 0.058^{\mathrm{e}}$ & $1.453 \pm 0.044$ \\
A. coronaria var. alba (Pure) & $2.431 \pm 0.087^{\mathrm{h}}$ & $2.204 \pm 0.047^{\mathrm{h}}$ \\
A. coronaria white cultivars of de Caen group & $1.548 \pm 0.091^{\mathrm{g}}$ & $1.714 \pm 0.095^{\mathrm{g}}$ \\
\hline
\end{tabular}

The Tables shows that the differences among "a" and A. coronaria var. coccinea pure group, " $b$ " and A. coronaria scarlet cultivars "e" and A. coronaria var. cyanea pure group, "f" and A. coronaria violetblue cultivars, "g" and A. coronaria var. alba pure group, "h" and A. coronaria white cultivars are statistically significant $(\mathrm{p}<0.05)$.

Table 2. Measurements of pores $(\mu \mathrm{m})$ in equatorial view.

\begin{tabular}{llc}
\hline Groups & \multicolumn{2}{c}{ Equatorial view } \\
\cline { 2 - 3 } & Pore width $(\mu \mathrm{m})$ & Pore length $(\mu \mathrm{m})$ \\
\hline A. coronaria var. coccinea (Pure) & $4.901 \pm 0.190^{\mathrm{b}}$ & $6.190 \pm 0.329^{\mathrm{b}}$ \\
A. coronaria scarlet cultivars of de Caen group & $3.457 \pm 0.201^{\mathrm{a}}$ & $4.147 \pm 0.210^{\mathrm{a}}$ \\
A. coronaria var. rosea (Pure) & $6.167 \pm 0.322^{\mathrm{d}}$ & $6.975 \pm 0.338^{\mathrm{d}}$ \\
A. coronaria pink cultivars of de Caen group & $3.848 \pm 0.121^{\mathrm{c}}$ & $5.026 \pm 0.221^{\mathrm{c}}$ \\
A. coronaria var. cyanea (Pure) & $4.305 \pm 0.226^{\mathrm{f}}$ & $5.205 \pm 0.279$ \\
A. coronaria violet-blue cultivars of de Caen group & $3.010 \pm 0.118^{\mathrm{e}}$ & $4.709 \pm 0.198$ \\
A. coronaria var. alba (Pure) & $5.097 \pm 0.278^{\mathrm{h}}$ & $7.163 \pm 0.239^{\mathrm{h}}$ \\
A. coronaria white cultivars of de Caen group & $3.186 \pm 0.181^{\mathrm{g}}$ & $4.357 \pm 0.215^{\mathrm{g}}$ \\
\hline
\end{tabular}

The Tables shows that the differences among "a" and A. coronaria var. coccinea pure group, "b" and A. coronaria scarlet cultivars, "c" and A. coronaria var. rosea pure group, "d" and A. coronaria pink cultivars, "e" and A. coronaria var. cyanea pure group, "f" and A. coronaria violet-blue cultivars, "g" and A. coronaria var. alba pure group, "h" and A. coronaria white cultivars are statistically significant $(\mathrm{p}<0.05)$.

It was thought that the reason for the reduction in the exine and intine layers of the pollens belonging to commercial cultivars could be attributed to the use of agricultural chemicals to produce a lot of flowers and rapid growth. It was reported that different fungicides and activator treatments had significant effects on the germination, the tube growth and the morphology of pollens. All fungicides reduced the percentage of pollen germination, length of germ-tube elongation and morphological features of almond (Prunus dulcis) pollen (Zarrabi and Imani 2011). Öztürk Çalı and Candan (2010) stated that the ACT-2, a K-vitamin group activator treatments reduced the exine-intine layer thickness and width-length measurements of tomato (Lycopersicon esculentum Mill.) pollen. In another study, Equation Pro ( $22.5 \%$ famoxadone $+30 \%$ cymoxanil) fungicide caused morphological deformity and thinner wall layers in the pollen of tomato 
(Lycopersicon esculentum Mill.) (Öztürk Çalı 2009). Additionally, the germination and the tube length of olive pollen were reduced when three insecticides (Dimethoate, deltamethrine and oleoparathion) were applied in vitro and in vivo to olive pollen culture media. In contrast, applications of the insecticide oleoparathion most severely reduced pollen germination, retarded germination, ruptured pollen tubes and damaged stigmatic surfaces in vivo in the same study (Mehri et al. 2007). According to Öztürk Çalı (2008), the fungicide fosetly-Al caused non-viable pollens types, such as wrinkled pollens or pollens with abnormal shapes. These were discovered in the Lycopersicon esculentum Mill. pollen. Moreover, pollen viability level decreased as the dosage increased in the same study.
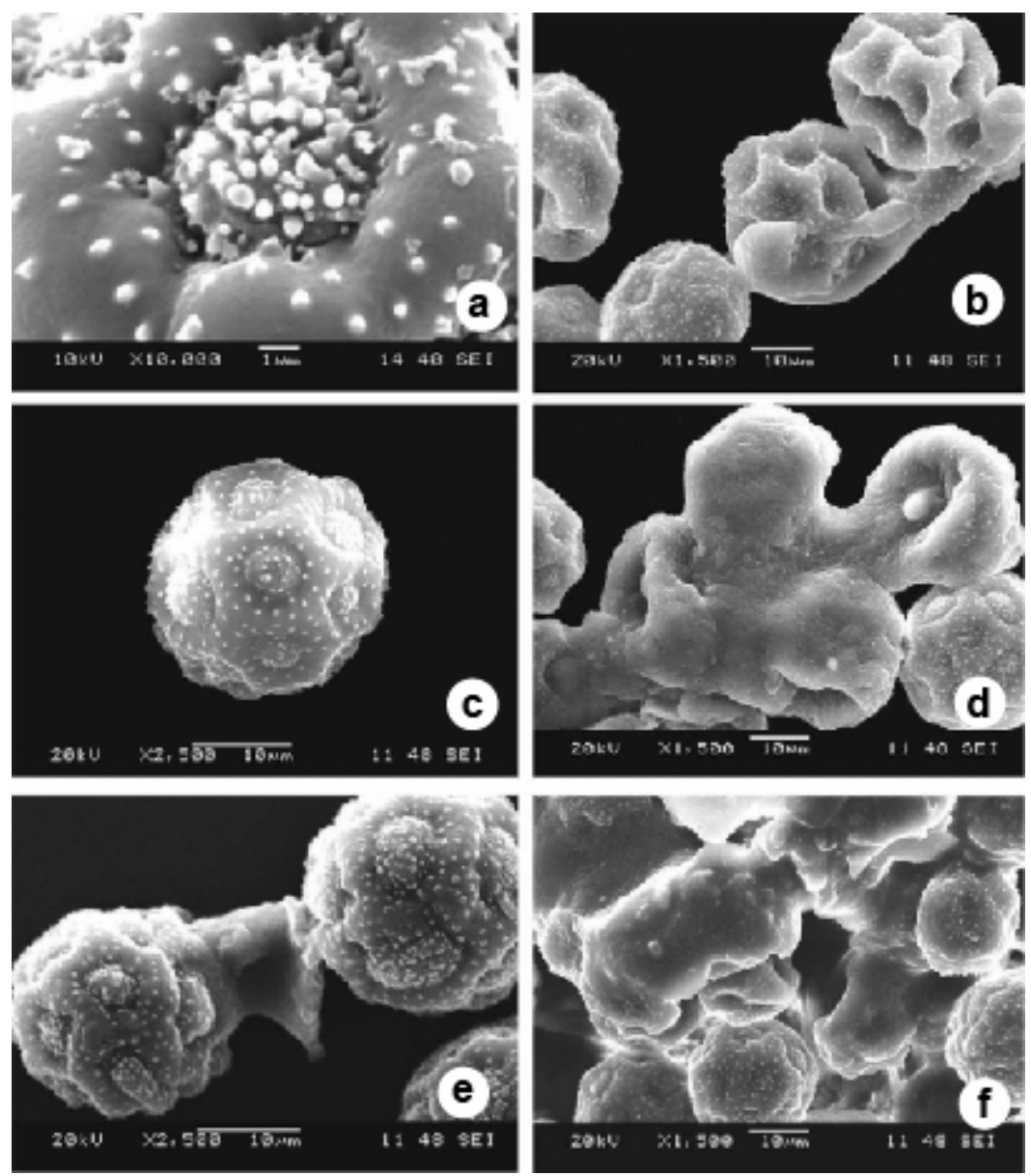

Fig. 2. SEM photographs. (a) The general appearance of the pollen in the pure Anemone coronaria var. coccinea (Jord.) Burn. with the spinules on the exine of the pollen. (b) Disappearance of the spinules on the surface layers of the pollens in the commercial A. coronaria red cultivars (c) Anomaly in the structure and the shape of pores in the commercial Anemone coronaria pink cultivars pollens (d) Disappearance of the spinules and the pores on the surface layers of the commercial Anemone coronaria violet-blue cultivars pollens. (e) Some changes on the shape of pores on the surface layers of the commercial Anemone coronaria white cultivars pollens. (f) Disappearance of the spinules and the pores on the surface layers of the commercial Anemone coronaria white cultivars pollen. 
Many studies showed detrimental effects of hybridization on the pollen viability in the commercial cultivars (Bures et al. 2010, Gay 1957). No study has been carried out on Anemone for knowing the effects of hibridization on the exine and intime layer. The present paper was the first study which examined the effects of hybridization on the mesurements of the exine and intine layers of Anemone coronaria.

When the results were evaluated with regards to width and length of pores in the equatorial view, it was generally seen that there was a decrease in the pore width and pore length values (Table 2). This decrease in the pore width of all the de Caen cultivar groups pollens was statistically significant as compared to the pure groups $(\mathrm{p}<0.05)$. Besides, the decrease that occurred in the pore length of the de Caen cultivar group pollens except for Anemone coronaria violet-blue cultivars as compared to the pure groups was found to have a statistical significance $(\mathrm{p}<0.05)$.

Several studies have been carried out on the detrimental effects of pesticides on the lengthwidth measurements of pollens in the equatorial and polar views (Öztürk Çalı and Candan 2009, Öztürk Çalı 2008). Another reason could be the hybrid nature of the Anemone L. varieties. Although there are many studies on the effects of hybridization on the pollen morphology of plants (Datta et al. 2006, Henderson 1972), there is no publication about the influence of hybridization on the pore measurements of the pollens in the commercial cultivars. In this study, it was found for the first time that there was a decrease in the pore measurements of the commercial cultivars pollens due to hybridization.

In the study, it was also determined that there were some changes on the surface layers of the de Caen commercial species of Anemone L. pollens. The spinules on the exine of the pollens observed in the varieties had disappeared on the commercial cultivars pollens. In addition to this, formation of a rare perforation formation of the structure was observed on the exine of the pollens regarding the cultivars (Fig. 2). Moreover, some anomalies were seen on the structure and shape of the pores in the commercial cultivars of de Caen group pollens. Ravi and Nair (1986) studied three species of Gloriosa L. and their three hybrids and observed that the pollen exine patterns in the hybrids were different from the patterns of the parent plants. Öztürk Çalı and Candan (2009) also stated that the fungicide Agri Fos 400 (400 g/l mono and di-potassium phosphanate) caused changes on the surface layer of pollen in the Lycopersicon esculentum Mill.

It was concluded that there were noteworthy differences in the exine-intine and pore widthlength measurements of the pollens in the de Caen cultivar groups as compared to the pure groups. The reasons for differences, might be the pesticides used to increase the growth during the commercial cultivation of the forms using of the tetraploid $\mathrm{F}_{1}$ hybrid Anemone $\mathrm{L}$. forms to produce more beautiful and big flowers than the pure ones.

\section{References}

Bures P, Smarda P, Rotreklova O, Oberreiter M, Buresova, Konecny J, Knoll A, Fajmon K and Smerda J 2010. Pollen viability and natural hybridization of Central European species of Cirsium. Preslia 82: 391 422.

Datta K, Chaturvedi M and Ram T 2006. Pollen exine ornamentation in the $\mathrm{F}_{2}$ generation of an interspecific hybrid of Chorisia (Bombacoideae, Malvaceae) in relation to inheritance pattern. Grana 45: 109-114.

Davis PH 1965. Anemone. Flora of Turkey. Edinburg University Press. Edinburg. pp. 134- 138.

Erdtman G 1966. Pollen Morphology and Plant Taxonomy Angiosperms. Hafner Publishing Company, New York and London.

Gay PA 1957. Aspects of the phytogeography of some Lusitanian Ericaceae in the British Isles. Ph.D. thesis, University of London, London, England. 
Heimburger M 1962. Cytotaxonomic studies in the genus Anemone. Can. J Bot. 37:587-612.

Henderson DM 1972. The hybrid pollen of Meconopsis6cookei. Grana 12: 52-56.

Kamenetsky R and Okubo H 2013. Ornamental Geophytes: From basic science to sustainable production. USA, CRC Press, Taylor and Francis Group.

Laura M and Allavena A 2007. Anemone coronaria Breeding: Current status and perspectives, Europ. J. HortSci. 72(6): 241-247.

Mehri H, Mehri-Kamoun R and El Mahjoub M 2007. In vitro and in vivo evaluation of 3 insecticides and bioinsecticide effects on olive pollen germination and tube growth. J Agronomy 6(4): 518-525.

Nepi M, Ciampolini F and Pacini E 1995. Development of Cucurbita pepo pollen: Ultrastructure and histochemistry of the sporoderm. Can. J. Bot. 73: 1046-1057.

Ohkawa K 1987. Growth and flowering of Anemone coronaria L. de Caen. Acta Hort. 205: 159-167.

Öztürk Çalı İ 2008. The effects of fosetyl-Al application on morphologyand viability of Lycopersicon esculentum Mill. pollen. Plant Soil Environ. 54(8): 336-340.

Öztürk Çalı İ 2009. Effects of A fungicide on polen morphology and fertility of tomato (Lycopersicon esculentum Mill.). Bangladesh J. Bot. 38(1): 7-11.

Öztürk Çalı İ and Candan F 2009. The effect of fungicide application on pollen structure in tomato (Lycopersicon esculentum Mill.). Plant J. App. Biol. Sci. 3(1): 56-59.

Öztürk Çalı İ and Candan F 2010. The effect of activator application on the anatomy, morphology, and viability of Lycopersicon esculentum Mill. pollen. Turk. J Biol. 34: 281-286.

Ravi Kumar C, Nair P K K 1986. Inheritance of exine ornamentation and pollen shape in interspecific tetraploid hybrids of Gloriosa. Can. J. Bot. 64: 3134-3140.

Tukey JW 1954. Some selected quick and easy methods of statistical analysis. Trans of New York Acad Sci., p. 88-97.

Wodehouse RP 1965. Pollen Grains. Hamer Press, New York. pp. 249.

Zarrabi A and Imani A 2011. Effects of fungicides on in vitro pollen germination, tube growth and morphology of almond (Prunus dulcis). African J. Agr. Res. 6(25): 5645-5649.

Ziman SN, Bulakh EV, Kadota Y and Keener CS 2008. Modern view on the taxonomy of the genus Anemone L. sensu stricto (Ranunculaceae). J. Japan. Bot. 83(3): 127-155.

(Manuscript received on 22 July, 2013; revised on 19 June, 2014) 